Review

\title{
Racial Profiling as Collective Definition
}

\author{
Trevor G. Gardner \\ Law School, New York University, 40 Washington Square S, New York, NY 10012, USA; \\ E-Mail: trevor.gardner@law.nyu.edu; Tel.: +1-212-988-6060; Fax: +1-212-995-3673
}

Submitted: 25 June 2014 | Accepted: 9 July 2014| Published: 17 September 2014

\begin{abstract}
Economists and other interested academics have committed significant time and effort to developing a set of circumstances under which an intelligent and circumspect form of racial profiling can serve as an effective tool in crime finding-the specific objective of finding criminal activity afoot. In turn, anti-profiling advocates tend to focus on the immediate efficacy of the practice, the morality of the practice, and/or the legality of the practice. However, the tenor of this opposition invites racial profiling proponents to develop more surgical profiling techniques to employ in crime finding. In the article, I review the literature on group distinction to discern its relevance to the practice and study of racial profiling. I argue that the costs of racial profiling extend beyond inefficient policing and the humiliation of law-abiding minority pedestrians and drivers. Racial profiling is simultaneously a process of perception and articulation of relative human characteristics (both positive and negative); it binds and reifies the concepts of race and criminality, fixing them into the subconscious of the profiled, the profiler, and society at large.
\end{abstract}

\section{Keywords}

African-American; criminality; criminal propensity; group boundary; group formation; racial profiling; sociology; social closure

\section{Issue}

This review is part of the special issue "Policing Ethnicity: Between the Rhetoric of Inclusion and the Practices and Policies of Exclusion", edited by Professor Abby Peterson (University of Gothenburg, Sweden) and Professor Malin Åkerström (University of Lund, Sweden).

(C) 2014 by the author; licensee Cogitatio (Lisbon, Portugal). This article is licensed under a Creative Commons Attribution 4.0 International License (CC BY).

\section{Introduction}

The body of feelings which scholars, today, are so inclined to regard as constituting the substance of prejudice is actually a resultant of the way in which given racial groups conceive of themselves and of others. A basic understanding of race prejudice must be sought in the process by which racial groups form images of themselves and others. This process...is fundamentally a collective process. (Herbert Blumer, 1958, p. 3)

Contemporary analysis of racial profiling by criminologists and economists tends to focus narrowly on questions addressing the utility of profiling for crime finding and the presence or absence of racial animus among profiling officers (Engel, Calnon, \& Bernard, 2002; Engle, 2008; Knowles, Persico, \& Todd, 2001; Skolnick \& Caplovitz, 2001; Gross \& Livingston, 2002; Dominitz \& Knowles, 2006) to the exclusion of less immediate yet profound sociological implications. As a result of the limited scope of the racial profiling debate, profiling scholars increasingly miss the proverbial forest for the trees. In the forthcoming discussion, I pivot from the issue of racial profiling efficacy to that of the social construction of race in the context of racial profiling. I argue that when police engage in racial profiling race and criminality take shape as co-constituted social constructs that inform a sense of racial hierarchy.

In the context of police work, the racial profile should be understood as distinct from a witness description. A profile, for the purposes of the my analysis, 
is a police conception of a hypothesized, criminally active person while a witness description (which may include race or ethnicity in combination with other descriptors) is witness generated and used to capture suspects only after a criminal allegation has been reported. Thus, police receive the witness description from a first-hand observer of a criminal action, whereas the profile is constructed and deployed by the police officer and/or the police institution based on the anticipated social location of a crime for which there is no witness or direct evidence. Unlike the witness description, which is offered by a witness to a crime that has allegedly transpired, police employ the racial profile without direct knowledge of criminal activity afoot. The profile informs the police officer's expectation of precisely where to find criminal activity. In developing the profile, the profiler anticipates the characteristics of the perpetrator, who is an abstraction rather than a real person.

My project in this paper is to use sociological investigations into the social construction of social groupsboth subordinate and superordinate-to illuminate the co-construction of race and criminality through the tactic of racial profiling. By drawing theories regarding group formation and group distinction into a racial profiling literature dominated by quantitative assessment, I hope to initiate and encourage an analysis of the impact of racial profiling that extends beyond the objective effectiveness of the practice in locating criminal activity afoot. I look instead to the potential for racial profiling to instill in the minds of the profiler, the profiled, and society at large the essential characteristics of those individuals affiliated with the targeted racial category.

The remainder of the paper is broken into three sections. In Section 2, I present a brief overview of the literature assessing the utility of racial profiling via statistical analysis. While offering an informative debate on the immediate effectiveness of racial profiling, quantitative studies have failed to consider many of the sociological costs of the practice. I review sociological studies regarding the social production of social groups and social group boundaries in Section 3 as part of an effort to clearly articulate these costs. In Section 4 , I delineate the process by which racial profiling establishes racial characteristics in a three-part schematic. I conclude that racial profiling by police fortifies and conflates racial and criminal group classifications, and that this negative distinction is in effect a statesponsored project in collective definition.

\section{The Efficacy Question}

Criminal law scholars in conjunction with a number of economists have turned to the question of the efficacy of racial profiling, specifically, the extent to which the targeting of members of a racial group reduces criminal activity (Knowles et al., 2001; Hernández-Murillo \&
Knowles, 2004; Harcourt, 2004; Harcourt, 2006; Borooah, 2001). Many of the scholars writing in this school argue that police may engage in racial profiling absent racial animus and, likewise, use racial profiling as a benign and effective tool for identifying criminal activity (Engle et al., 2002). The logic of such argumentation holds that racial profiling stemming from racial animus should show a criminal activity "hit rate" (i.e., a positive finding of criminal conduct per stop/investigation) among the profiled group that is lower than that of individuals outside the profiled group. If the hit rate of the targeted racial group is equal to or greater than that of the rest of the population despite heightened police scrutiny, the profiling practice is thought to be based on rational grounds rather than irrational racial bias. This latter outcome, in theory, affirms the efficacy of the practice and serves as prima facie evidence that the police use race in a benign fashion rather than in a manner intended to harm or subjugate the profiled racial group (Harcourt, 2004, p. 1293).

Scholars have critiqued statistical models constructed to test for "benign" racial profiling, primarily by evaluating their effectiveness in revealing criminal activity and criminal actors. For instance, alternative statistical analyses exploring the "elasticity" of racial profiling show that racial profiling efficacy has less of a deterrent effect on African-Americans than on other groups given the challenges African-Americans face in finding alternative income streams. Associated findings suggest that racial profiling may ultimately increase the total amount of criminal activity in a given setting given that non-profiled groups are likely to recognize when police attention is narrowly focused elsewhere (Harcourt, 2004).

A few academic treatments of racial profiling have challenged the practice from a more sociological point of view, conveying the racializing elements inherent to the act as an important outcome to be considered. UCLA Law Professor Devon Carbado begins his critique of Supreme Court decisions regarding the practice of racial profiling with an account of the first few years after his immigration to the United States (Carbado, 2002). Carbado, a British national, found himself subject to racial profiling soon after he arrived in the U.S., and while he initially expressed anger during each incident of perceived police abuse, he eventually concluded that his claims of racial bias only served to complicate already precarious police encounters. Carbado writes that he soon adopted the role of the passive African American male, intent on letting each momentary police intrusion end without further incident. These experiences collectively served as a "naturalization ceremony within which our submission to authority reflected and reproduced black racial subjectivity" (Carbado, 2002, p. 957). Cabado states plainly, "We were growing into our American profile" (p. 958).

I wish to link Carbado's anecdotal illustration of the 
impact of racial profiling on the transformation of his own subjectivity to sociological knowledge regarding the utility of race in establishing group distinction, group hierarchy and collective subjectivity in a given social setting. This orientation toward the study of racial profiling shifts the outcome analysis from "crime finding" to the less immediate issue of the dissemination of social meaning by way of a specific form of state-sponsored group distinction. When applied to the subject of racial profiling, the sociological study of the production of group distinction reveals that role-play in the profiling moment produces a specific understanding of social hierarchy for the profiled, and the profiler. Through similar scripts played out countless times each day, citizens and police alike come to naturalize racial categories and racial role-play based on subordinate and superordinate racial group status.

\section{The Dynamic Process of Group Distinction}

Despite its role as a pervasive and daunting force in American society, "race" exists largely as a social construct and as a product of public definition (Omi \& Winant, 1994; Brubaker, 2004; Wacquant, 2004; Lopez, 2006; Davis, 2010). That is to say that race does not exist outside of collective understanding of the concept and acquiescence to its predetermined logics. Scholars of racial group formation and racial prejudice have thoroughly examined and theorized the social process of creating artificial, bounded categories to which individuals are assigned (Hacking, 1996). Though categorization serves a natural and necessary way of understanding the social world, the process itself establishes distinctions that can immediately transform collective perception of social reality (Hacking, 1996). The categorized subject often arises within and through the dynamic process of categorization.

The claim of dynamic nominalism is not that there was a kind of person who became increasingly to be recognized by bureaucrats or by students of human nature but rather that a kind of person came into being at the same time as the kind itself was being invented. In some cases, that is, classifications and our classes conspire to emerge hand in hand, each egging on the other (p. 228).

The institutionalization of categories and labels often impacts the extent to which a social group is assigned meaning within the public consciousness. The institutional mobilization of social group categories through institutional practices such as racial profiling set a path for new societal perspectives on the social world and thus new social realities. Institutional classifications shape public understandings.

Scholars have identified the "dramatization of evil" in the context of the criminal processing of the crimi- nally accused within similar conceptual parameters (Tannenbaum, 1957). For instance, the moment when a young person is first placed in contact with the criminal justice system serves as a pivotal point in the youth's relationship with the state and the community and, likewise, in the development of her perception of self. To the extent that the criminal act results in the state's application of a criminal identity, the youthnow categorized as "deviant" and "defendant" - falls into a binary with the community (Tannenbaum, 1957). If, alternatively, the community frames the youth's contact with the judicial system in cooperative terms, all invested parties might be more likely to continue to view that child as a part of (rather than alien to) the community. In the application of criminal labels, the act rather than the child's life circumstance or constitution comes to represent the child to the state forum and to society. The conceptualization of the child as criminal-a "dramatization of evil" in the institutional context of criminal procedure-is understood to have a powerful normative effect. It shapes a new subjectivity for the child in which the child plays the role of a deviant suffering from a dysfunctional disposition rather than the role of a child having committed a single deviant act.

The expanded role of police in school discipline is another telling example of the impact of dramatization. As school administrators employ full time on-site police forces, the school as an institution often "dramatizes" and criminalizes behavior that has been found in every schoolyard for centuries past (Fine et al., 2003). This is not to discount the destructive impact incidents of violence can have on a school community. It is instead to highlight how particular penal responses-locked exits, on-site police, and routine criminal charging-establish penal norms and penal identities in the minds of student, teacher, and administrator alike (Fine et al., 2003). These norms are not benign. They inform group distinctions by way of conceptualization-here, between bad behavior in school and criminal deviance. If a child recognizes that she is being regulated in a manner similar to a prison, she accepts that stage and script and is thus to some degree conditioned to play the role appropriate for the setting.

Goffman's idea of "stigma symbols" provides another frame by which to conceptualize the manner in which social cues come to characterize social groups (Goffman, 1963). Through symbols, social information is conveyed to the social actors in a given setting. Children attending school under lock and key in the name of their own security are not per se criminals, but develop criminal perspectives of themselves by way of the signals embedded in the school setting (Goffman, 1963, p. 46). "The normal and the stigmatized are not persons but rather perspectives. These are generated in social situations during mixed contacts by virtue of the unrealized norms that are likely to play upon the 
encounter" (1963, p. 138).

Race theorists have similarly argued race conceptualization and the cultivation of racial stigma to be a "fundamentally collective process" (Blumer, 1958). In this line of analysis, racial prejudice stems from the identification one's own racial group relative to another, and requires a clear and functional understanding of how each group is defined to the exclusion of the other. Thus, in order to conceive of two races, both must be defined in terms of particular group characteristics. Racial prejudice cannot exist unless the social position and character of each group is apparent to the social actor. Moreover, such prejudice requires racial corollaries, namely a specific conceptualization of a subjugated and dominant group (Blumer, 1958). In taking the constitution of racial groups for granted rather than accounting for their dynamic social production, social actors and institutions ignore the tacit ways in which specific conceptualizations of race inform human thought, perception, action, and speech and likewise group division in social life. Through these diverse social processes our minds structure and come to perceive and act upon the social world (Brubaker, Loveman, \& Stamatov, 2004).

People around the world trade in "common sense" (yet variable) racial categories based on the notion that race and ethnicity exist as fixed and essential qualities (Brubaker, 2002). The institutionalization of race has been a significant subject of sociological study in part because it sheds light on the classification processes that can establish racial distinction (2002, p. 167). Critical analysis of such processes can pinpoint fundamental elements of racial conflict and perception of racial threat.

This [analytical orientation] means thinking of ethnicity, race, and nation not in terms of substantial groups or entities but in terms of practical categories, cultural idioms, cognitive schemas, discursive frames, organizational routines, institutional forms, political projects, and contingent events. It means thinking of ethnicization, racialization, and nationalization, as political, social, cultural, and psychological processes. And it means taking as a basic analytical category not 'the group' as an entity but groupness as a contextually fluctuating conceptual variable. (p. 167)

Symbolic power, which manifests in various processes of group distinction, can serve as an essential cog in the process of collective understanding (Bourdieu, 1973). Through symbols, society coalesces to create shared meaning. Symbols are at the core of the process of public definition and the achievement of shared meaning, as well as the vehicle by which meaning is imposed on the public; they are fundamental to the reification of the social order. But more than organizing a collective reality, the symbolism underlying human taxonomy holds the potential to commit "symbolic violence" in its facilitation of group domination. The term "racial stereotype," for instance, is central to this discussion, but its common understanding fails to capture the dynamic, collective, and variable quality of racial group distinction. The stereotype is a basic conceptualization of the symbolic power that facilitates the production and dissemination of racial distinction (Bourdieu, 1973, p. 169). Rather than being the product of arbitrary mental processes, racial stereotypes are triggered by symbols and are borne of symbolic power. They are thought to arise from natural inclinations, but survive by way of systems of classification and corresponding mental structures that adhere to a larger and implicit race orthodoxy (Bourdieu, 1973).

In shaping social groups and establishing group boundaries, we use established categories as readily accessible packets of information that help us comprehend the social world. Micro, person-to-person interactions inform racial categories and racial distinctions, as do the meso-level actions of institutions, particularly public institutions, which are recognized as representing affiliated publics and as operating in accordance with the public will. To understand both how racial meaning is produced and how it is digested in a given social moment, one must critically assess the role of the state in fostering and reifying racial distinction. This analytical orientation has yet to be applied to the case of racial profiling by police.

\section{Racial Profiling and Racial Group Distinction}

To characterize another racial group is, by opposition, to define one's own group. This is equivalent to placing the two groups in relation to each other, or defining their positions vis-a-vis each other. It is this sense of social position emerging from this collective process of characterization which provides the basis for prejudice. (Herbert Blumer, 1958, p. 4)

The practice of racial profiling begins with a process of racial distinction that takes place in the mind of the police officer or in the formulation of policing policy. The profiling act itself informs the collective definition of race by articulating racial group characteristics and, by logical extension, racial group relations and relative racial group standing.

\subsection{Constructing Race in Criminal Justice}

In the following discussion I look to establish a basic framework for the manner in which racial profiling policy and practice convey group distinction to various segments of society within the distinct levels of formulation and execution. In the three hypothesized "theaters" of racial profiling presented in the framework, specific segments of society witness or participate in 
racial profiling, or in some way come to understand racial profiling as a state-sponsored security project. As a result, criminal characteristics attach to the targeted racial classification. The three theaters are not mutually exclusive as one or all may manifest in the racial profiling moment.

Theater I: Lone Officer Construction of Racial Meaning: The individual officer makes an independent and autonomous decision to profile a targeted racial group member on the street in the context of a cursory investigation. Consider the following example. Patrol officers in a squad car stop a group of African-American men driving late in the evening in a predominantly white neighborhood and ask for identification and inquire as to their ultimate destination. The encounter escalates to the point where the officers place the men in handcuffs and sit them on the curb while conducting a search of the vehicle. In this scenario, an association between criminal propensity and African-American racial classification is conveyed to the profiling officer, the profiled subject, and witnesses to the profiling event.

Theater II: Institutional Construction of Racial Meaning-Internal: The police institution adopts an internal policy naming race as one of a litany of indicia of criminality. Race is defined to all members of the police institution and all other employees privy to the policy. The profiling act by the lone officer in Theater $I$ is not predicated on racial profiling policy, as in Theater II. However, if the police institution formally establishes that officers should associate a racial classification with criminal propensity, the conceptual association becomes ingrained within the police institution. Institutional construction of racial meaning in Theater // facilitates, endorses, and encourages profiling by officers in the field and informs the quality of their engagement with those associated with the targeted racial category. In Theater II, the conflation of race and criminality is no longer limited to the autonomous mind of an individual officer. The conflation is instead explicit within the institution and legitimated by the institutional authority. In Theater II, profiling loses its secretive character and some of its accompanying stigma, and extends the coconstruction of race and criminality from the calculation of a single individual in a private sphere to the institutional consciousness encompassing the police collective.

Theater III: Institutional Construction of Racial Meaning-External: The judicial, legislative, or executive branch of the local, state, or federal government publicly endorses profiling. Here, the public institution endorsing racial profiling validates the practice in the "collective consciousness." Racial profiling appears to be the product of careful deliberation by elected leaders and/or ostensibly democratic institutions. The conflation of racial classifications and criminal propensity finds public acceptance. For the sake of pragmatism, deliberations about public safety include the contem- plation of race, perhaps even regretfully. In advancing from Theater I to Theater II, the construction of racial meaning advances from the individual to the institutional, from the implicit to the explicit, from a function of culture to an element of structure. ${ }^{1}$ In the move from Theater II to Theater III, the construction of racial meaning comes to serve as an element of societal or public knowledge, informing the collective understanding of race rather than merely the institutional understanding.

\subsection{Racial Meaning in Washington, D.C.}

An incident in Washington, D.C., in 2006 helps to illustrate the relationship between the three theaters of racial profiling and racial group distinction. After a highprofile murder in the city's wealthy and largely white Georgetown area, Andy Solberg, a white police commander for the city district that included Georgetown, addressed a meeting of concerned local residents at a neighborhood church. In reference to the homicide, Solberg offered the group what he likely understood to be common-sense tips on neighborhood safety.

I would think that at 2 o'clock in the morning on the streets of Georgetown, a group of three people, one of whom is 15 years old, one of whom is a bald chunky fat guy, are going to stand out... They were black. This is not a racial thing to say that black people are unusual in Georgetown. This is a fact of life (The Washington Times, 2006).

When Solberg's comments became a top local news story, Charles Ramsey, the city's African-American police chief, initially offered public support for the 19year department veteran, saying that Solberg was a "very, very good guy" and had done great work in the area of city in which he served as commander (Klein, 2006). An African-American store owner in Georgetown interviewed by The Washington Post seemed startled at the controversy saying, "How come people don't know that? These people live in a box? It is highly, highly unusual to see three young black males roaming around up there in the residential neighborhoods." Charles Lawrence, an African-American, a former D.C. School Board Council member and a friend of Solberg

\footnotetext{
${ }^{1}$ An example can be found in an FBI policy proposed by the Justice Department (DOJ) in 2008. In July of 2008, the Associated Press reported that DOJ had formulated a policy that would allow the FBI to investigate Americans absent a report of wrongdoing. Under the policy, the FBI would construct a "terrorist profile" that included race and ethnicity, and use data mining techniques to formulate a list of subjects to be investigated. Attorney General Mukasey denied that Americans would be investigated solely because of race, but left the door open to race and ethnicity being used to construct a basis of suspicion (Jordan, 2008).
} 
said that he regretted the public criticism. In describing the commander he pointed out that Solberg sent his children to a public school that was 95\% AfricanAmerican and coached a local soccer team that was nearly entirely African-American. "What we really need is more white folks who are not going to run and hide but are committed to living here like Andy. I don't know any white person in the city who is less afraid of or more fair about race" (Fisher, 2006). Ramsey reinstated Solberg to his original position two weeks after assigning him to another district (Klein, 2006).

This account of racial profiling in Washington, D.C. (a city fondly referred to in some circles as "Chocolate City") seems remarkable in a number of other respects. First, and most relevant to the "theaters" framework, it demonstrates the external pressure police officials face in advancing racial profiling from Theaters I and II to Theater III. The narrative suggests that Commander Solberg, in advising Georgetown residents to racially profile, had relayed a tactic considered unexceptional in police circles. Solberg, acting in an advisory role to the Georgetown neighborhood community, prescribed racial profiling, and implicitly suggested that racial profiling among police was standard practice and "common sense." For the presumably largely white audience in attendance, he advised a particular understanding of African-American presence in Georgetown. Though the media reporting of Solberg's statement included backlash over the comments, the ensuing dialogue was a sincere public exploration of the extent to which race and criminality could legitimately be associated. Local media coverage of the incident does not show a single police official denouncing Solberg's statements or even disagreeing with his proposition to the Georgetown neighborhood group. In fact, the media record shows sparse dissent from Solberg's statements relative to the number of affirmations. Individual and internal bureaucratic assessments of the link between conceptions of race and criminality were ultimately disseminated to public forums and local and national media without direct challenge from the police institution.

Racial profiling conveys an implicit racial logic when it is an ad hoc, individual practice or insulated within the police institution. However, when adopted or inferred as institutional policy and publicized as either sound policy or a sensible neighborhood safety precaution, the societal impact of racial profiling grows substantially. Explicit approval of racial profiling policy by police, national security institutions, city councils, state legislatures, or Congress, publicly defines the profiled to the collective. It openly casts racial characteristics as fixed in a social context that is understood to be democratic and subject to the will of the people. At which point, the covert quality of racial profiling practice by an individual or within a closed institutional system yields to an advertised notion of criminality borne out of democratic deliberations rather than hidden hunch- es. Racial profiling in the theater of the public amounts to more than a moment of individual shame for targeted racial group members. It functions more broadly as a constructive enterprise that builds collective understanding of both race and criminality and reinforces this understanding through subsequent, innumerable police-public contacts.

\subsection{Race, Group Distinction, and Social Closure}

Sociologists have insisted that the process of racial distinction not be studied in a vacuum, but instead assessed as part of larger system of group boundary construction and maintenance (i.e., in relation to its codependence with social classifications such as class and criminal record) (Schwartzmann, 2007). Mara Loveman writes that, "[s]uch a framework could permit identification of the patterns of relations between particular social processes and particular structural conditions that trigger certain boundary dynamics; consequently, it could improve social scientific understanding, explanation, and theorization" (Loveman, 1997) (my emphasis).

The investigation of interdependent forms of social closure is significant to the development of a comprehensive understanding of the social consequences of racial profiling. The embrace of racial profiling functions as a form of social closure as it marks, stigmatizes, and isolates by disseminating theories of racial group distinction. The moment police choose to profile a racial group or a single group member, the characteristic of criminality is freshly assigned to the group in at least one of the three profiling theaters, typecasting the group, and calling for the anticipation of criminal conduct by other group members.

Police conflation of racial and criminal classification in the project of racial profiling ultimately aligns with a larger structural system of group subjugation. As the "black" racial classification becomes a proxy for criminality and dangerousness and state actors orient penal infrastructure to this predetermined racial target, the group draws closer to civic death (Wacquant, 2005). In the U.S., offenders are increasingly barred from college loans, welfare benefits, public housing, and the right to vote (Wacquant, 2005). Moreover, the ex-felon is unlikely to be hired as an employee in the public or private sector, or to secure funds for job training. The pattern of physical and symbolic exclusion produced through racial profiling policy and practice aligns with these collective penal effects to shape a robust racial-meaning making system that undergirds racial hierarchy.

\section{Conclusion}

Race and criminality are malleable social constructs subject to public definition. The meaning of the terms takes shape through rhetoric, policy, and implicit and 
explicit symbolism and role-play. A narrow focus on questions of racial profiling's utility in crime finding renders innocuous its important contributions to racial meaning. The racial profiling endeavor, as practice and policy, signals to society the loci of criminality. To find criminal activity, look there. To identify criminal propensity, look here. In contrast to the description given by a witness reporting a crime, racial profiling conveys instructions on how to anticipate crime. It primes the public to expect criminal acts from a specific category of persons, and in the process informs and exacerbates a form of social marginalization that has burdened the U.S. since its very inception.

\section{Conflict of Interests}

The author declares no conflict of interests.

\section{References}

Blumer, H. (1958). Race prejudice as a sense of group position. Pacific Sociological Review, 1(1), 3-7.

Borooah, V. K. (2001). Racial bias in police stops and searches: an economic analysis. European Journal of Political Economy, 17(1), 17-37.

Bourdieu, P. (1994). Language and symbolic power. J. B. Thompson (Ed.). Polity Press.

Brubaker, R. (2002). Ethnicity without groups. European Journal of Sociology, 43(02), 163-189.

Brubaker, R. (2004). Ethnicity without groups. Harvard University Press.

Brubaker, R., Loveman, M., \& Stamatov, P. (2004). Ethnicity as cognition. Theory and Society, 33(1), 31-64.

Carbado, D. W. (2002). (E)racing the Fourth Amendment. Michigan Law Review, 946-1044.

Davis, F. J. (2010). Who is black? One nation's definition. University Park: Penn State Press.

Dominitz, J., \& Knowles, J. (2006). Crime minimisation and racial bias: What can we learn from police search data? The Economic Journal, 116(515), F368F384.

Engel, R. S. (2008). A critique of the "outcome test" in racial profiling research. Justice Quarterly, 25(1), 1-36.

Engel, R. S., Calnon, J. M., \& Bernard, T. J. (2002). Theory and racial profiling: Shortcomings and future directions in research. Justice Quarterly, 19(2), 249-273.

Fine, M., Freudenberg, N., Payne, Y., Perkins, T., Smith, K., \& Wanzer, K. (2003). "Anything can happen with police around": Urban youth evaluate strategies of surveillance in public places. Journal of Social Issues, 59(1), 141-158.

Fisher, M. (2006, July 18). D.C.'s Reaction to Killing Misses the Point. The Washington Post. Retrieved from http://www.washingtonpost.com/wpdyn/con tent/article/2006/07/17/AR2006071701210_pf.html Goffman, E. (1963). Stigma: Notes on the Management of Spoiled Identity. Touchstone.

Gross, S. R., \& Livingston, D. (2002). Racial profiling under attack. Columbia Law Review, 102(5), 1413-1438.

Hacking, I. (1999). Making up people. In M. Biagioli (Ed.), The Science Studies Reader (pp. 161-171). Oxford: Routledge.

Haney-Lopez, I. (2006). White by law: The legal construction of race. New York: NYU Press.

Harcourt, B. E. (2004). Rethinking racial profiling: A critique of the economics, civil liberties, and constitutional literature, and of criminal profiling more generally. The University of Chicago Law Review, 71(4), 1275-1381.

Harcourt, B. E. (2006). Muslim Profiles Post 9/11: Is Racial Profiling an Effective Counterterrorist Measure and Does it Violate the Right to be Free from Discrimination?. Paper presented at the Oxford Colloquium on Security and Human Rights at Oxford University, Oxford, UK.

Hernández-Murillo, R., \& Knowles, J. (2004). Racial Profiling or Racist Policing? Bounds Tests in Aggregate Data. International Economic Review, 45(3), 959989.

Jordan, L. (2008). Senators Probe DOJ Politics, Potential Profiling. Associated Press. Retrieved from http://usatoday30.usatoday.com/news/washington /2008-07-09-2621760956_x.htm

Klein, A. (2006). Police Inspector Who Made Racial Remark Back at Job. The Washington Post. Retrieved from http://www.washingtonpost.com/wpdyn/con tent/article/2006/07/24/AR2006072400405.html

Knowles, J., Persico, N., \& Todd, P. (1999). Racial bias in motor vehicle searches: Theory and evidence (No. w7449). Cambridge: National Bureau of Economic Research.

Loveman, M. (1999). Is "Race" Essential?. American Sociological Review, 64(6), 891-898.

Schwartzman, L. F. (2007). Does money whiten? Intergenerational changes in racial classification in Brazil. American Sociological Review, 72(6), 940-963.

Skolnick, J. H., \& Caplovitz, A. (2001). Guns, Drugs, and Profiling: Ways to Target Guns and Minimize Racial Profiling. Arizona Law Review, 43, 413.

Stuntz, W. J. (2002). Local policing after the terror. Yale Law Journal, 111(8), 2137-2194.

Tannenbaum, F. (1957). Crime and the Community. New York: Columbia University Press.

Wacquant, L. (1997). For an analytic of racial domination. Political Power and Social Theory, 11(1), 221-234.

Wacquant, L. (2005). Race as civic felony. International Social Science Journal, 57(183), 127-142.

The Washington Times. (2006). Ramsey Institutes Crime Emergency. Retrieved from http://www. washingtontimes.com/news/2006/jul/11/20060711 $-113957-3104 r /$ ?page=all 


\section{About the Author}

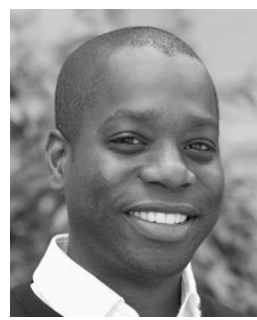

Dr. Trevor Gardner

Trevor Gardner is a Faculty Fellow/Assistant Professor at New York University Law School. Trevor received his J.D. from Harvard Law School in 2003 and worked as a public defender in the District of Columbia from 2003 to 2006, litigating both juvenile and adult criminal cases. He received his Ph.D. from the University of California, Berkeley, in 2014. Trevor's primary research interest is in policecommunity relations, namely the degree of authority neighborhood residents and local governments hold over associated police departments. 